\title{
Spreading herbivore manure in livestock farms increases soil carbon content, while granivore manure decreases it
}

\author{
Morgan Curien ${ }^{1} \cdot$ Alice Issanchou $^{1}$ (D) $\cdot$ Francesca Degan $^{2} \cdot$ Vincent Manneville $^{3} \cdot$ Nicolas P. A. Saby $^{4} \cdot$ Pierre Dupraz $^{1}$
}

Accepted: 26 February 2021 / Published online: 9 April 2021

(C) The Author(s) 2021

\begin{abstract}
Livestock farming occupies 57\% of agricultural area in France and has contrasting impacts on the environment. Studies have analyzed relations between livestock farming and soil organic carbon (SOC) content, but the influence of livestock farming on soils is difficult to perceive at a large scale. The objective of this study was to increase understanding of impacts of livestock farming on soils that receive livestock manure depending on different initial levels of SOC content, at cantonal level. To this end, we used French soil and agricultural databases to analyze relations between livestock farming practices and SOC content. We used statistical data calculated from the French soil test database for the periods 2000-2004 and 2010-2014. For livestock farming practices, we used data from the French agricultural census of 2000 and 2010, and for spreading of livestock manure, data from the French program to control pollution of agricultural origin (2002-2007) and data from the French Livestock Institute. The novelty of our large-scale analysis is to differentiate the origin of livestock manure (herbivore or granivore) and the type of crop on which it was spread (crops or grasslands). Statistical analysis was performed at the cantonal scale for France using the method of generalized least squares. We show for the first time that, at the national scale, spreading of livestock manure influences SOC content and dynamics significantly. Our results also show the importance of the nature of the manure; solid manure increases SOC content, unlike liquid manure. Spreading herbivore manure on crops increases SOC content, but spreading granivore manure may decrease it. Livestock manure spread on grasslands has no significant effect on SOC content, possibly due to under-representation of grassland soils in the soil database. These results demonstrate the importance of the complementary between crop and livestock to maintain soil ecosystem services, including soil fertility.
\end{abstract}

Keywords France $\cdot$ Livestock $\cdot$ Manure $\cdot$ Slurry $\cdot$ Soil database $\cdot$ Statistical analysis $\cdot$ Soil and climate conditions $\cdot$ Soil organic carbon $\cdot$ Carbon sequestration

\section{Introduction}

In France, livestock farming covers over half of the utilized agricultural area (UAA). Animal production systems differ in their grazing management and intensity, inclusion of grasslands in crop rotations, manure management, and type of farming system. This diversity of livestock farming systems leads to a diversity of

Alice Issanchou

a.issanchou@gmail.com

SMART-LERECO, AGROCAMPUS OUEST, INRAE, 35000 Rennes, France

2 Arvalis, Institut du végétal, 91720 Boigneville, France

3 Institut de l'élevage, 63170 Aubière, France

4 INFOSOL, US 1106, INRAE, 45000 Orleans, France environmental impacts, which depend on the farming practices implemented. Intensification of livestock farming can cause environmental impacts such as water pollution from nitrates, but less intensive livestock farming can provide many benefits, such as maintaining biodiversity in semi-natural areas through grazing or increasing soil organic carbon (SOC) sequestration (Dumont et al. 2019). Furthermore, temporary and permanent grasslands provide several ecosystem services: decrease in water erosion, SOC sequestration (Soussana et al. 2004), increase in functional diversity, and benefit to areas of high nature value (Dumont et al. 2019). However, specialization and concentration of farming livestock systems in certain areas have led to a decrease in grasslands in other areas (Xiao et al. 2015).

In addition, at the regional scale, livestock farming areas tend to have higher SOC content than arable farming areas (Paroissien et al. in review). SOC content is important for agricultural production since it improves soil properties, 
structure, aeration, and infiltrability, thus decreasing erosion, decreasing compaction (increasing bearing capacity), and increasing cation exchange capacity and plant nutrition (Loveland and Webb 2003). Livestock farming and arable farming areas are interconnected through exportation of straw and cereals from arable farming areas to livestock farming areas for animal litter and feed. However, the difference in SOC contents at the regional scale is not explained by these exchanges of organic matter but rather by differences in the use of livestock manure (LM) (Fließbach et al. 2007, Fig. 1), the presence of temporary grasslands in crop rotations (Yang and Kay 2001; West and Post 2002), and the proportion of permanent grasslands in the UAA (Loveland and Webb 2003).

Studies have analyzed SOC content and dynamics to assess impacts of livestock farming systems on soils at regional (Sleutel et al. 2003) and national scales (Bellamy et al. 2005). Regarding livestock farming, some decreases in SOC content have been explained by a decrease in the amount of organic matter spread, such as manure (Goidts and van Wesemael 2007; Capriel 2013). Other studies have attempted to explain dynamics of SOC content in France as a function of farming practices at regional scales, such as the regions Bretagne, Limousin, and Nord-Pas-De-Calais from 1980 to 1999 (Lemercier et al. 2006) and Franche-Comté (Saby et al. 2008) or Alsace from 1990 to 2009 (Swiderski et al. 2012). Regarding livestock farming, Saby et al. (2008) suggested that the decrease in SOC content was related to the decrease in grassland area. However, these studies could not assess direct impacts of livestock farming on SOC content. Furthermore, regional studies are not detailed enough to capture impacts of livestock farming on SOC content since livestock farming varies among livestock farming regions (Depeyrot et al. 2015).

A recent study (Paroissien et al. in review) showed that SOC dynamics in France depend on the period and the geographic area considered, with an increase in SOC content in crop farming areas. At the French national scale, several factors affect SOC dynamics: climate and soil (Chen et al. 2019), land-use type (e.g., woodland, vineyard, crop, grassland) (Saby et al. 2014), type of crop cultivated, crop rotation (Chen et al. 2019; Issanchou 2017), farming practices (e.g., tillage, mineral nitrogen use) (Chen et al. 2019; Issanchou 2017), and farm type (Sierra et al. 2017).

Although hypotheses exist about the relations between SOC, spreading of LM, and proportion of grasslands, no study at the French national scale has shown a direct relation between the number of livestock and SOC content. Paroissien et al. (in review) found no significant relation between the total number of livestock units and SOC dynamics in the main livestock farming regions in France. They may have obtained this result because their study did not consider the difference in quality or quantity of the manure produced by the types of livestock (e.g., cows, sheep, goats, poultry, and pigs), which were aggregated into livestock units, calculated from feed requirements. Martin et al. (2014) developed a model to estimate SOC content in French departments as a function of LM spreading (ADEME 2007) combined with dry matter C concentration (Meersmans et al. 2012). Meersmans et al. (2012) obtained inconsistent results for the relation between spreading of LM and SOC content. Currently, manure spreading data from ADEME (2007) are available at the departmental scale, which we considered too coarse to provide consistent results when SOC content is mapped at a resolution of $250 \mathrm{~m}$.
Fig. 1 Spreading of solid livestock manure on a field (Source - image by Hans Braxmeier from Pixabay)

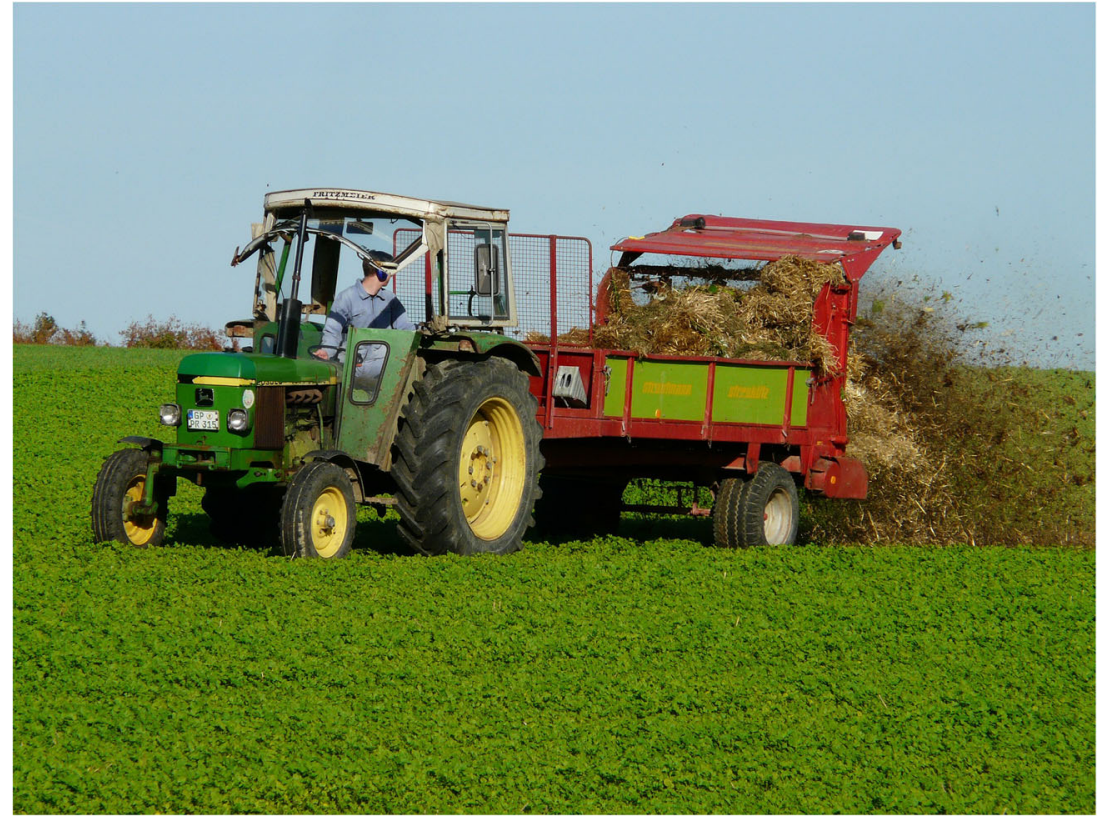


These studies were unable to demonstrate a relation between livestock farming practices and SOC content and dynamics at regional or national scales, although a positive impact of livestock farming on SOC content through manure management has been recognized in other studies (Dumont et al. 2019). Thus, the objective of this study was to increase understanding of impacts of livestock farming on soils, specifically the effect of LM spreading on SOC content. This study will investigate the impacts of livestock systems on SOC via a statistical approach using a large dataset based on census data, soil properties, climate indicators, and farm practices available at the French level. We also tested whether the impacts of livestock systems vary depending on different initial levels of topsoil quality, when soils are either initially poor or rich in SOC content, at the cantonal level in France.

\section{Materials and methods}

To study the relation between livestock farming and SOC dynamics, we used data on agricultural topsoil quality, census data on farm practices, and climatic data. The different information used in this study had different spatial resolution; we therefore harmonized them at a canton resolution to run the statistical analysis.

\subsection{Livestock manure spread}

We estimated, at the cantonal scale, the total amount of LM spread on the UAA by source (herbivore vs. granivore), by type of production (solid vs. liquid), and by destination (crops vs. grasslands).

A database from ADEME (2007), the French Ecological Transition Agency, contains estimates of LM spreading at the departmental scale, but this scale is too large to capture the relation between LM spreading and SOC content (Meersmans et al. 2012). Although the number of livestock units is available at the cantonal scale, it seems to have no statistically significant relation with SOC content, likely due to differences between herbivore and granivore manure (Paroissien et al. in review). Thus, the amount of LM spread at the cantonal scale must be estimated as a function of the types of livestock present. We also distinguished the type of LM produced (solid vs. liquid) and its destination (crops vs. grasslands). We expressed the amount of LM spread in terms of its dry matter content to obtain a total amount of LM spread per canton, which we ultimately converted to a mean amount of LM spread per hectare on crop and grassland areas.

To estimate the amount of LM produced by herbivores and granivores, we used data from the 2000 and 2010 French agricultural censuses. The difference between the LM produced and the LM spread is given by the French program to control pollution of agricultural origin (PMPOA 2007). The number of herbivores corresponds to the number of dairy and suckler cows, other cattle, ewes, other ovines, goats, and other caprines. In the calculation of LM of herbivores, livestock units are based on nutritional requirements of each type of herbivore (definition of IDELE) and are used as coefficients for the different types of herbivores. The number of granivores corresponds to the number of sows, fattening pigs, and poultry. The LM of sows and fattening pigs is computed separately from the LM of poultry. The time of presence in the farm buildings of each type of animal, the proportion of solid or liquid manure in LM, the amount of agricultural land per farm type, and land cover type where LM was spread were obtained from the second French program to control pollution of agricultural origin (PMPOA 2007). The amount (Mg) of solid and liquid LM per animal or per livestock unit was obtained from the French Livestock Institute (IDELE). The dry matter content of solid and liquid LM was obtained from French technical institutes (IFIP, ITAVI, IDELE). In addition, the manure of ewes, other ovines, goats, and other caprines was only solid. The liquid waste mentioned in the 2000 agricultural census corresponds to organic waste from milk processing (washing water from animal exploitation facilities and equipment on the farm). All LM from sows and fattening pigs was liquid, and they were assumed to be present on the farm throughout the year (PMPOA 2007). For poultry, we assumed that $60 \%$ of the LM was solid and $40 \%$ was liquid in each canton. Total LM equaled total LM of herbivores and total LM of granivores. The LM produced by herbivores was estimated for each canton as follows:

LM herbivores $=$ LM herbivores solid

$$
+ \text { LM herbivores liquid }
$$

where

LM herbivores solid $=$ number of herbivores

$$
\begin{aligned}
& \times \text { livestock units } \\
& \times \text { time of presence in the farm buildings } \\
& \times \text { proportion of solid LM } \\
& \times \text { t of solid LM per livestock unit per year } \\
& \times \text { dry matter content }
\end{aligned}
$$

and

$$
\begin{aligned}
& \text { LM herbivores liquid }=\text { number of herbivores } \\
& \qquad \times \text { livestock units } \\
& \quad \times \text { time of presence in the farm buildings } \\
& \quad \times \text { proportion of liquid LM } \\
& \quad \times \text { tof liquid LM per livestock unit per year } \\
& \quad \times d r y \text { matter content }
\end{aligned}
$$

The LM produced by granivores was calculated for each canton as follows: 
LM granivores $=L M$ solid for sows and fattening pigs

$$
\begin{aligned}
& + \text { LM solid for poultry } \\
& + \text { LM liquid for sows and fattening pigs } \\
& + \text { LM liquid for poultry }
\end{aligned}
$$

where

$$
\begin{aligned}
& \text { LM solid for sows and fattening pigs } \\
& =\text { number of sows and fattening pigs } \\
& \quad \times \text { time of presence in the farm buildings } \\
& \times \text { proportion of solid LM } \\
& \times \text { t of solid LM per animal per year } \\
& \quad \times \text { dry matter content }
\end{aligned}
$$

and

\section{LM liquid for sows and fattening pigs}

$$
=\text { number of sows and fattening pigs }
$$

$\times$ time of presence in the farm buildings

$\times$ proportion of liquid $L M$

$\times t$ of liquid LM per animal per year

$\times$ dry matter content

and

LM solid for poultry $=$ number of poultry

$\times$ time of presence in the farm buildings

$\times$ proportion of solid LM

$\times t$ of solid LM per animal per year

$\times$ dry matter content

and

LM liquid for poultry $=$ number of poultry

$\times$ time of presence in the farm buildings

$\times$ proportion of liquid $L M$

$\times$ t of liquid LM per animal per year

$\times$ dry matter content

To estimate the LM spread per hectare and per land-use type, we distinguished the destination (crops vs. grasslands) by using two additional datasets: the surface area on which LM was spread (SAMS), which is available at the regional scale for livestock farms of several economic and technical orientations (e.g., dairy and suckler cows, other cattle, small ruminants, and granivores), and the UAA at regional and cantonal scales. The SAMS data (Institut de l'élevage 2007), obtained from PMPOA (2007), indicate the proportions of LM spread on maize, grasslands, cereals, and other farms. Spreading on other farms is rare except for granivore manure, especially in the region of Bretagne, where experts estimate that farms often reach the regulatory limit of $170 \mathrm{~kg}$ of organic nitrogen applied per hectare. In this case, the surplus LM is spread on cereals. Thus, we limited the destinations of organic matter to grasslands and "cereals" (i.e., the sum of cereals, maize, and "other farm" destinations).

To downscale the regional SAMS data to the cantonal scale, we used cantonal UAA to estimate the proportion of each canton's UAA in cereals and grassland. The amount of LM spread on cereals and grasslands per hectare in each canton was calculated as follows:

Cantonal weighted SAMS on cereals

$$
\text { = regional SAMS }
$$

$$
\times \frac{\text { proportion of cereals in the canton }}{\text { proportion of cereals in the region }}
$$

Cantonal weighted SAMS on grasslands

$$
\begin{aligned}
= & \text { regional SAMS } \\
& \times \frac{\text { proportion of grasslands in the canton }}{\text { proportion of grasslands in the region }}
\end{aligned}
$$

We normalized the two cantonal weighted SAMS so their sum would equal one, as follows:

$$
=\frac{\begin{array}{c}
\text { Cantonal normalized SAMS on cereals } \\
\text { cantonal weighted SAMS on cereals }
\end{array}}{\left(\begin{array}{c}
\text { cantonal weighted SAMS on cereals }+ \text { cantonal weighted SAMS on grasslands }) \\
\text { cantonal weighted SAMS on grasslands }
\end{array}\right.}
$$

Then, we calculated the amount of LM spread on cereals and grasslands per hectare in each canton as follows:

$$
\begin{gathered}
=\frac{\sum \text { Cantonal LM spread on cereals per ha }}{\text { cantonal cereal UAA }} \text { by type of livestock } \times \text { cantonal normalized SAMS on cereals } \\
\text { Cantonal LM spread on grasslands per ha } \\
=\frac{\sum \text { total LM by type of livestock } \times \text { cantonal normalized SAMS on grasslands }}{\text { cantonal grassland UAA }}
\end{gathered}
$$

\subsection{Soil data}

Information about agricultural topsoil quality corresponded to summary statistics computed at a canton level using soil test results stored in the French Soil Tests database (Base de 
Données d'Analyses de Terres-BDAT) (INRAE 2018; Saby et al. 2014). This database is the output of a national French program that aims at storing results of soil tests commissioned mainly by farmers to manage the fertilization of their plots. The results were provided by ca. 30 soil-testing laboratories certified by the French Ministry of Agriculture, all of which applied the same analytical standards. This database stores soil test results from more than 2.6 million agricultural plots spread over the French mainland and sampled from 1990 to 2014. The sampling depth corresponded on average to 0 and $25 \mathrm{~cm}$ for crop soils and 5 to $15 \mathrm{~cm}$ for grassland soils (Schvartz et al. 1997). To respect the confidentiality of the plot owner, the sampling location is not perfectly known and corresponds to the area of the municipality. The sampling resolutions in space and time are heterogeneous as the sampling protocol is not controlled. These constraints are factored into the statistical analyses by computing summary statistics of the soil test results per spatio-temporal entities. As already presented, we pooled the data in space per canton as this resolution matched the one of the LM spread data. In time, we pooled the data per 5-year period and we focused on two time-periods-2000-2004 and 2010-2014 - since SOC dynamics involve slow processes. Moreover, these periods matched the date of the census campaigns of the LM spread data (2000 and 2010).

We retained in this study information about SOC content $(\mathrm{gC} / \mathrm{kg})$ and soil texture (i.e., clay, loam, sand). We computed for every spatio-temporal entity, the mean, the first and last decile of these soil indicators. The SOC changes were computed as described in Saby et al (2017). A resampling technique is proposed to consider the possible bias in the database.

The sampling protocol associated with the data collection procedure of the soil data may be referred to as a purposive sampling design. This type of design does not guarantee getting unbiased estimates of the parameters of the statistical distributions (De Gruijter et al. 2006). However, we assumed in this study that the bias could be reduced if the number of observations per canton is large enough, with at least 50 soil test results. However, given high variability in the proportion of UAA in the area of French cantons, the amount of soil tests had to be a function of sampling density per hectare UAA rather than of the number of analyses per canton. The minimum sampling density of soil test results was set at 50 soil test results divided by the average percentage of the UAA of French cantons in the 2000 and 2010 agricultural censuses. This corresponded to an average of one soil analysis sample per 145 ha. Using this resampling protocol, we have selected cantons for which we observed this minimum density of soil test results for 2000 and 2010 .

Finally, we had two sets of data: one dataset where we selected cantons for which data were available; one subdataset where we selected cantons with a minimum sampling density of soil test results (1 soil test per $145 \mathrm{ha}$ ) (see Fig. 2).
Fig. 2 Map of the selected cantons for the two datasets used in this study (Source- from the authors)

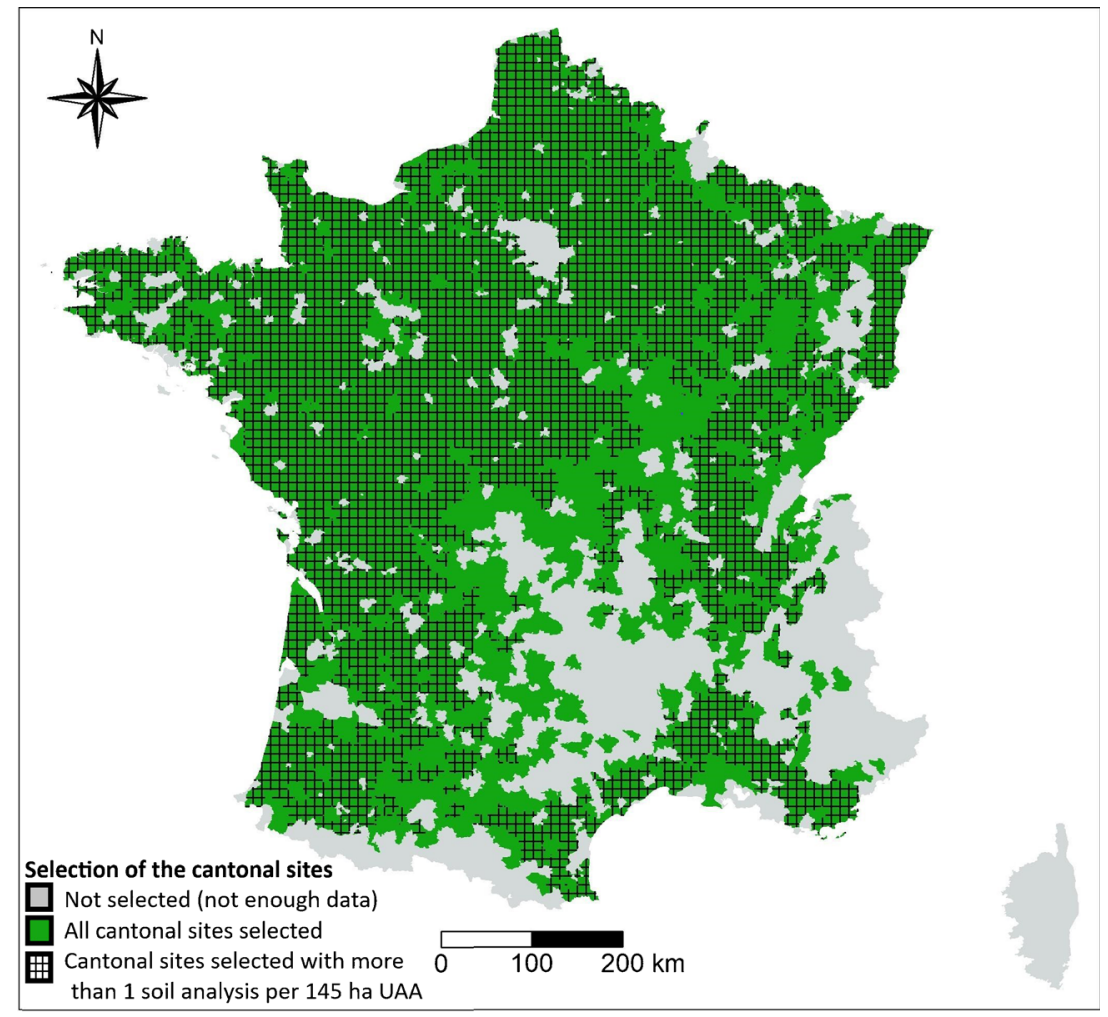




\subsection{Climatic data}

As SOC dynamics is impacted by temperature and moisture (Chen et al. 2019), we used a set of climatic indicators based on annual statistics at the cantonal scale from 1970 to 2010 obtained from Joly et al. (2010). We retained two sets of indicators. The first one corresponds to the absolute value of different indicators: number of hot days (above $30^{\circ} \mathrm{C}$ ), inter-annual variability in temperatures in July (the SD of the 30 monthly temperature values during the reference normal), and inter-annual variability in monthly precipitation in July and January (the SD of the 30 monthly precipitation values during the reference normal).

\subsection{Farm practice data}

Farm practice data used in the statistical analysis were obtained from the 2000 and 2010 French agricultural censuses. We retained the proportions of cereals, oilseed crops, protein crops, forage maize, and temporary and permanent grasslands in the UAA of each canton.

\subsection{Statistical analysis}

We selected as the variables to be explained the first and last deciles and the mean of the topsoil SOC content for the period 2010-2014 and the change in SOC content between 20002004 period and 2010-2014 period. The explanatory variables used were soil and weather variables, UAA occupied (by cereals, oilseed crops, forage maize, and temporary and permanent grasslands), SAMS variables, and LM variables. Statistical relations between SOC variables and farming practices were estimated as follows:

- Calculate correlations between all pairs of explanatory variables.

- Remove all explanatory variables with high correlations.

- Test for homoscedasticity and normality (Shapiro test).

- Standardize the explanatory variables and the explained variables.

- Perform multiple linear regression using the generalized least squares method when the homoscedasticity test was rejected (always the case) or the hypothesis of normality test was rejected (never the case).

- Minimization of the Akaike information criterion (AIC) to select the most parsimonious model.

We used the general least square approach rather than a machine learning approach in order to explain the relationships between the explanatory variables and the explained variables, with information about the statistical significance and the signs of the relationships, while machine learning algorithms are better suited to provide accurate predictions (Wadoux et al. 2020). We have standardized the variables to ease the comparison and the interpretation of the statistical analysis. Statistical analyses were performed using R software (v.3.5.1) (R Core Team 2018) and the interface Rstudio (v.1.3.1073). To conduct the linear regressions, we used the packages nlme (v.3.1-149; Pinheiro et al. 2020) and lmtest (v.0.9-38; Zeileis and Hothorn 2002).

\subsection{Impact of LM spreading on SOC content in $\mathbf{2 0 1 0}$}

Two regressions of SOC content in the period 20102014 as a function of LM spreading were performed for each canton: one considering the destination of the LM (i.e., cereal and maize areas vs. grassland areas) (regression 1) and the other ignoring the destination of the LM but considering the total amount of herbivore and granivore manure spread (regression 2). For this regression, the relation between SOC content at the cantonal scale for the period 2010-2014, and farming practices and land-use types in 2010 was tested. To better understand the effect of the variability of the SOC content, we fitted the regressions with one of three statistical indicators of the initial values of SOC content for the period 2000-2004 (i.e., mean, first decile, or last decile) as the control variable "SOC content 2000." This step represented a sort of sensitivity analysis where we tested whether the impacts of livestock farming variables on SOC content and dynamics vary depending on different initial levels of topsoil quality. Mean weather and soil texture data were used and assumed to remain constant over time.

Regression 1:

SOC content in period 2010-2014

$$
\begin{aligned}
= & \alpha_{i} \text { control variables }+\beta_{i} U A A \text { land use variables } \\
& +\delta_{1} S A M S \text { from herbivores on cereals } \\
& +\delta_{2} S A M S \text { from herbivores on grasslands } \\
& +\delta_{3} S A M S \text { from granivores on cereals } \\
& +\delta_{4} S A M S \text { from granivores on grasslands } \\
& +\delta_{5} \text { total LM from herbivores }+\varepsilon
\end{aligned}
$$

Regression 2:

SOC content in period 2010-2014

$$
\begin{aligned}
= & \alpha_{i} \text { control variables }+\beta_{i} \text { UAA land use variables } \\
& +\delta_{1} \text { total LM from herbivores } \\
& +\delta_{2} \text { total LM from granivores }+\varepsilon
\end{aligned}
$$




\subsection{Impact of LM spreading on the change in SOC content from 2000 to 2010}

Two regressions of change in SOC content from the period 2000-2004 to the period 2010-2014 as a function of LM spreading were performed (Eq. 17): one considering all cantons and the other considering only cantons in which at least an average of one soil analysis sample per 145 ha was performed. We considered the impact of farming practices on the change in SOC content from 2000-2004 to 2010-2014. We considered farming practices during the initial period (2000) and the change in farming practices from 2000 to 2010.

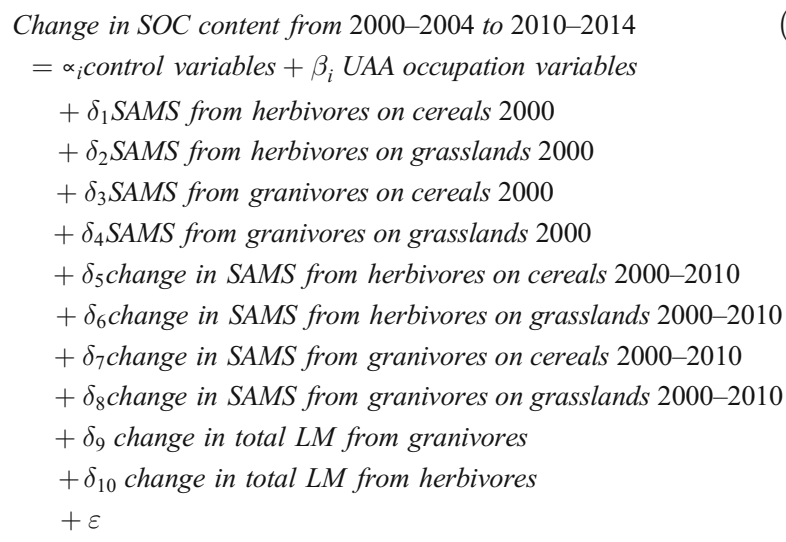

We also ran a sensitivity analysis. Regressions were calculated for all four values of SOC content in each canton (i.e., median, mean, first decile, and last decile) to capture differences in dynamics and behavior of soils as a function of their initial SOC content (see Fig. 3).

Unfortunately, using the cantonal weighted SAMS to estimate LM spreading resulted in a significant negative impact of herbivore manure spread on crops or grasslands on SOC content (results not shown). This result is not consistent with the literature on the agronomic value of farm fertilizers or large-scale analysis of impacts of LM spreading on SOC content (Goidts and van Wesemael 2007; Capriel 2013). Consequently, we used each region's SAMS values to represent those of its cantons and assumed that SAMS values at the two scales were similar.

\section{Results and discussion}

The distributions of the SOC at the two periods are provided in Fig. 3. Within the mean and last decile of SOC cantonal values, there is a much more elongated distribution than for the first decile. Indeed, there are more outliers within the last decile values, especially for the 2010-2014 period, than in other deciles. This could suggest a possible impact of agricultural practices to increase carbon content in some contexts. The difference from first to second time period reveals, for each decile, a less pronounced multimodal distribution. However, for the first decile, the median value increases from the first to the second period. This evolution is less important in the median values of the other deciles.
Fig. 3 Distribution of the soil organic carbon (SOC) for the periods 2000-2004 and 20102014 (Source - from the authors)

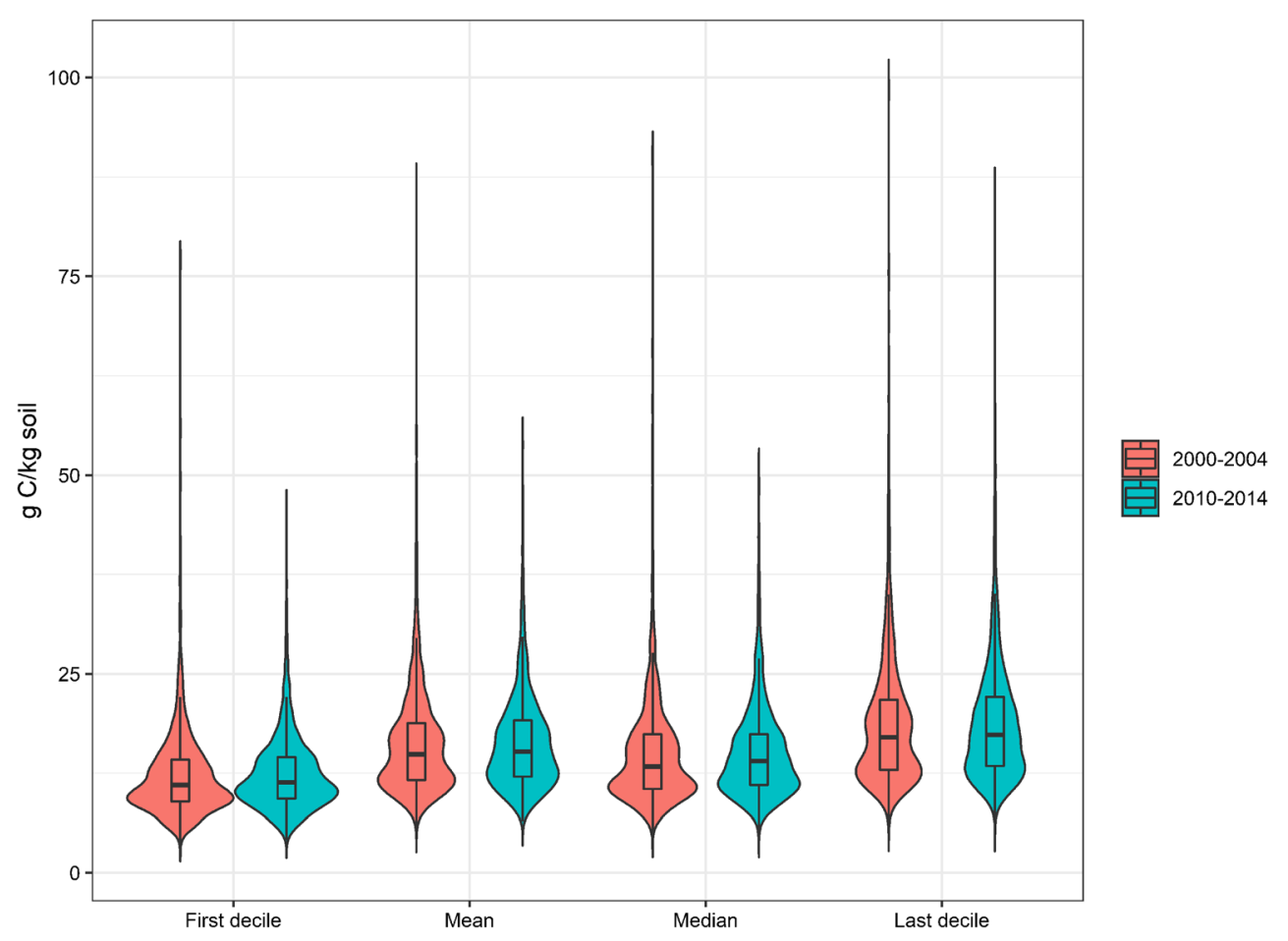


Fig. 4 Estimated coefficients and statistical significance at $10 \%$ level of general least squares regression of soil, weather, and farming practices on three values for the soil organic carbon (SOC) content (first decile, mean, last decile) of 2010-2014 at the cantonal scale in France considering the destination of the livestock manure (LM) (i.e., cereal and maize areas vs. grassland areas) and all cantons (regression 1) (source-from the authors, adapted from Curien 2018).

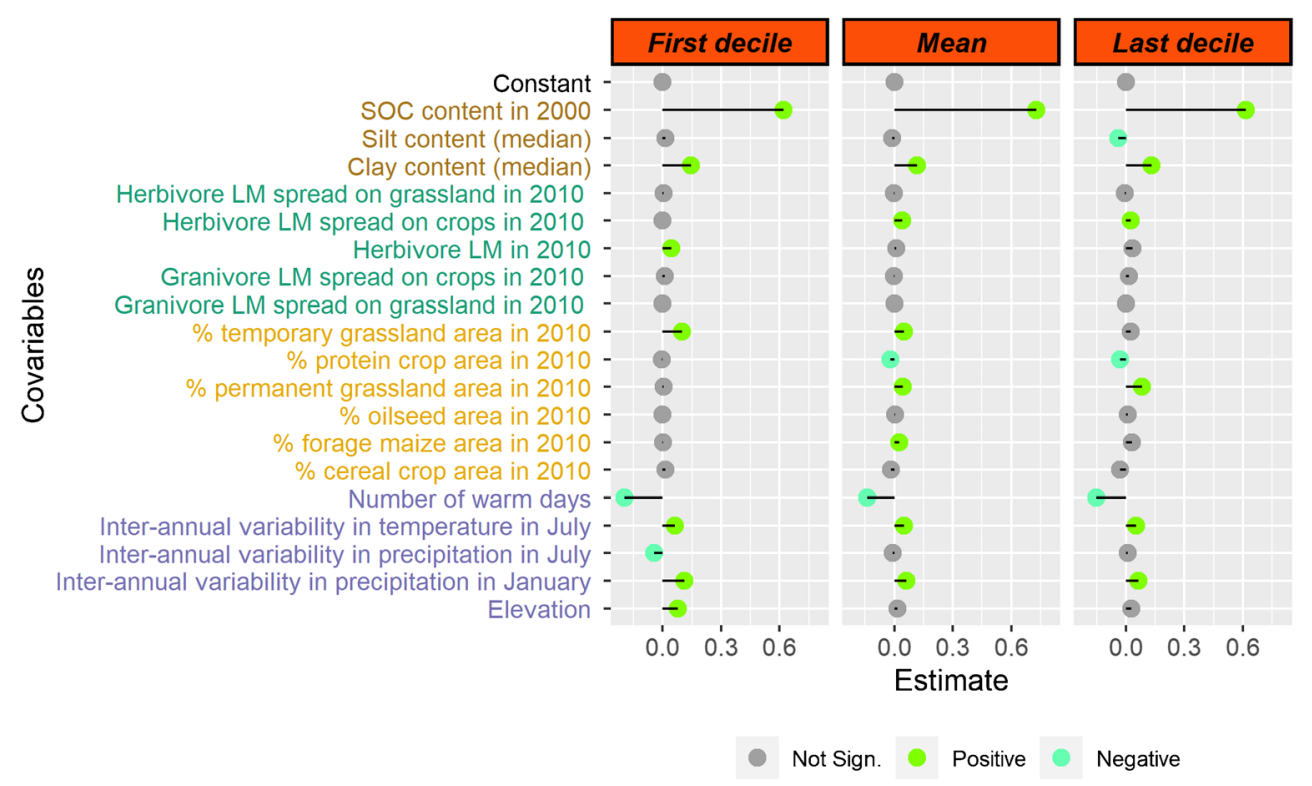

The correlation matrices indicate the relevant covariables to consider in regression (see the supplementary material S. Figure 1 for the correlation matrix for carbon content variables and S. Figure 2 for the correlation matrix about soil carbon evolutions). In particular, the first decile of carbon content (for both time periods) is quite well correlated with the mean number of hot days in climate types.

As expected, mean SOC contents of the two periods were significantly and positively correlated (Figs. 4 and 5). In addition, initial SOC content had a significantly negative impact on SOC dynamics, regardless of the value used for it, which illustrates soil's resilience to change (Figs. 5 and 6). The impacts of the other control variables, inter-annual variability in temperature in July, inter-annual variability in precipitation in January, elevation, and median clay content were significantly and positively correlated with SOC content, as observed by Paroissien et al. (in review), and with the change in SOC content. The ranking of the impacts of the explanatory variables on SOC content and changes is confirmed when running a machine learning algorithm (cubist and random forest models).

\subsection{Impact of land use on SOC content}

Regarding land-use types, cantonal proportions of cereals and oilseed crops in 2010 had no significant impact on SOC content (Figs. 4, 5, 6, and 7). However, the AIC procedure selected the cantonal proportion of cereals, suggesting that it did have explanatory power (see Table 3 and Table 4 in the supplementary materials). The cantonal proportion of protein crops had a significantly negative impact on mean and last
Fig. 5 Estimated coefficients and statistical significance at $10 \%$ level of general least squares regression of soil, weather, and farming practices on three values for the soil organic carbon (SOC) content (first decile, mean, last decile) of 2010-2014 at the cantonal scale in France ignoring the destination of the LM but considering the total amount of herbivore and granivore manure applied and all cantons (regression 2) (Source-from the authors, adapted from Curien 2018)

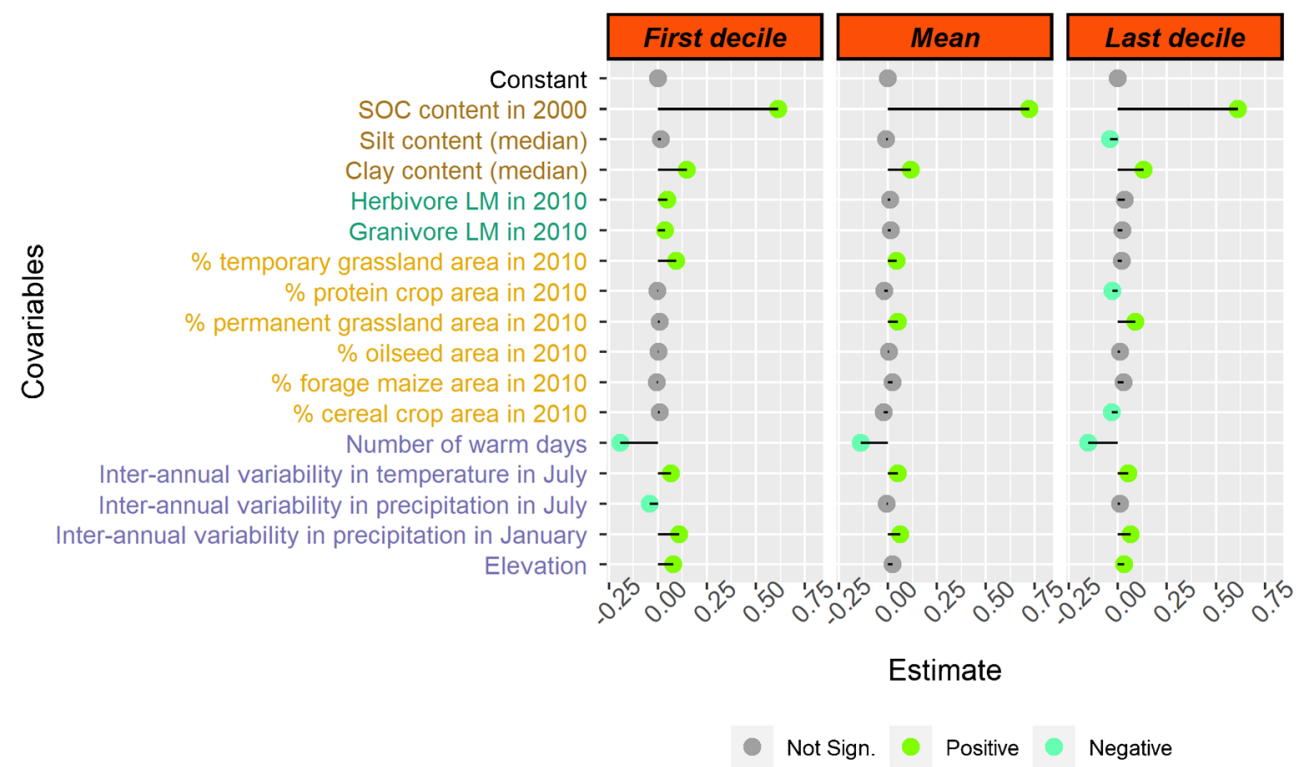


Fig. 6 Estimated coefficients and statistical significance at $10 \%$ level of general least squares regression of soil, weather, and farming practices on three values for the change in soil organic carbon content from 2000-2004 to 2010-2014 (first decile, mean, last decile) at the cantonal scale in France considering all cantons (regression 3) (Source - from the authors, adapted from Curien 2018)

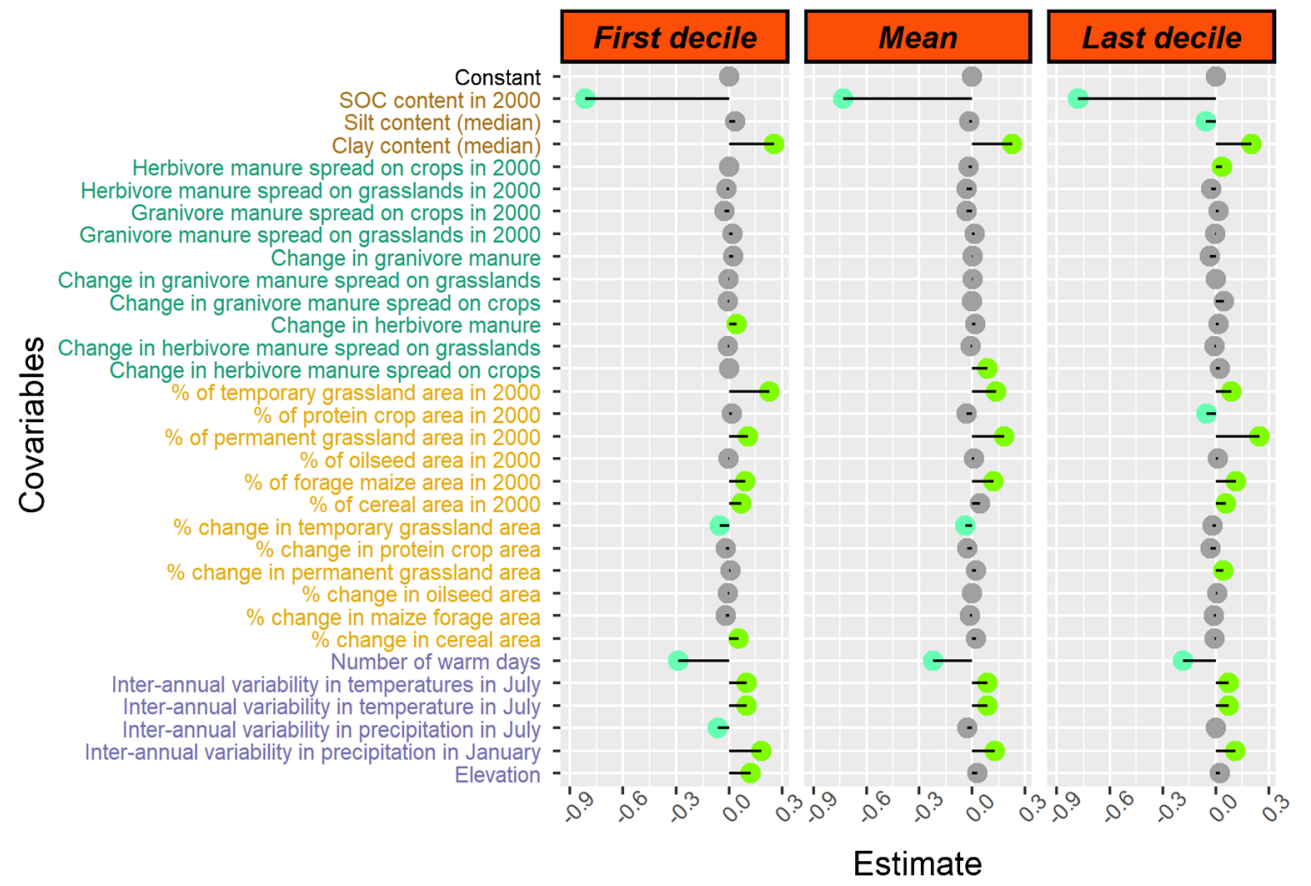

Not Sign. Positive Negative decile values of SOC content. Proportions of forage maize and temporary and permanent grasslands had a significantly positive impact on SOC content. Paroissien et al. (in review) obtained similar results for grasslands, while Issanchou (2017) calculated a positive impact of forage maize on SOC content (third-quartile value) but none for grain maize. This can be explained by two indirect effects. Forage maize is usually grown in livestock farming areas and livestock manure is more likely to be spread on these crops than on grain maize areas. Besides, forage maize often replaces temporary grasslands within a rotation and as such benefits from the backward effect of the former grasslands SOC content.
Fig. 7 Estimated coefficients and statistical significance at $10 \%$ level of general least squares regression of soil, weather, and farming practices on three values for the change in soil organic carbon content from 2000-2004 to 2010-2014 (first decile, mean, last decile) at the cantonal scale in France considering cantons in which at least an average of one soil analysis sample per 145 ha was performed (regression 4) (Source-from the authors, adapted from Curien 2018)

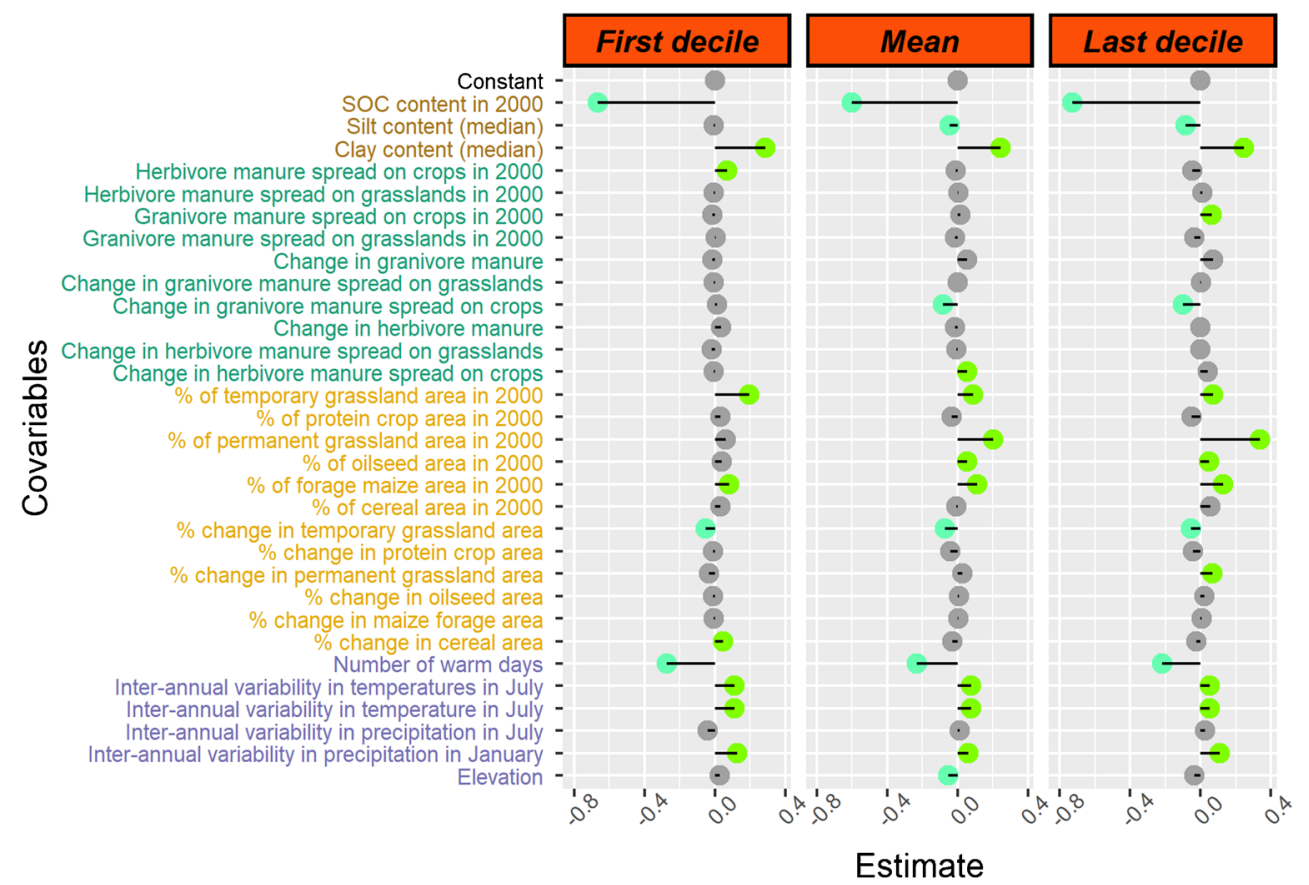

Not Sign. Positive Negative 
However, when considering SOC dynamics (Figs. 6 and 7), the increase in the cantonal proportion of cereals had a significantly positive impact on the first decile change in SOC (i.e., a decrease in SOC content). There were no contradictions between regressions 1 and 2. Actually, cereals covered most UAA in crop-producing regions, where SOC content was lower than in other types of regions (Paroissien et al. in review). Cereal crops are usually included in short crop rotations, which usually have lower SOC contents than areas with longer crop rotations (West and Post 2002) or where perennial crops are included at the beginning of the rotation (Yang and Kay 2001). In our results, cereal area did not influence mean and median SOC contents or its dynamics significantly. Other studies have observed a positive impact of an increase in cereal area (Issanchou 2017), likely due to incorporation of crop residues into the soil.

The change in cantonal proportions of forage maize, oilseed crops, and protein crops had no significant impact on that in SOC content (Figs. 6 and 7). The negative impact of protein crops on SOC content can be explained by the exportation of all their above-ground parts for feed, production of less biomass than Poaceae, and the increase they cause in the labile (i.e., easily mineralized) pool of C in the soil (Blair and Crocker 2000).

The change in the cantonal proportion of temporary grasslands had a significantly negative impact on that in SOC (Figs. 6 and 7), perhaps due to the conversion of fields with low soil quality into temporary grasslands. The cantonal proportion of temporary and permanent grasslands or forage maize had a positive impact on SOC content and dynamics (Figs. 4, 5, 6, and 7). Unlike previous studies based on BDAT data (Issanchou 2017; Paroissien et al. in review), other studies have found a negative impact of maize area on SOC content (Loveland and Webb 2003). Currently, when grasslands are converted, they are usually converted into maize (Dumont et al. 2019), which corresponds to an intensification of livestock farming. When soil from a maize field is analyzed and has a high SOC content, it is usually the impact of the preceding grassland that is measured. In addition, herbivore manure is more likely to be spread on forage maize than on other crops.

The cantonal proportion of permanent grasslands had a positive impact on SOC content and dynamics (Figs. 4, 5, 6, and 7); however, the change in the proportion of permanent grasslands did not have a significant impact on that in SOC (Figs. 6 and 7). According the literature, however, permanent grasslands have a positive impact on SOC content (Loveland and Webb 2003). However, SOC content increases more slowly under permanent grassland than it decreases when the grassland is converted to crop cultivation (Soussana et al. 2004). Furthermore, only $20 \%$ of the cantons considered had increased their proportion of permanent grasslands, which along with under-representation of grasslands in BDAT, may explain the non-significant results obtained.

\subsection{Impact of livestock manure on SOC content}

Herbivore manure spread on grasslands and granivore manure spread on crops and grasslands did not impact SOC content significantly (Fig. 4). Besides the under-representation of grasslands in BDAT, other factors can explain these results. For one, livestock deposit their manure on grasslands when they graze, which is not considered in our data, and environmental conditions and management influence whether grazing increases, decreases, or has no impact on SOC content (McSherry and Ritchie 2013). The effect of grazing on SOC content depends on many factors, such as soil type, precipitation, photosynthesis, grazing intensity, and the depth of the soil sampled (McSherry and Ritchie 2013). Thus, at a large scale, local impacts of LM on grasslands (i.e., at the plot scale) can be mitigated. Furthermore, grassland soils have higher SOC content than crop soils (Saby et al. 2014), and SOC content increases more slowly in grasslands soils than in crop soils for a given amount of organic matter applied.

Without considering the destination of the LM spread, the total amount of herbivore and granivore manure spread in a canton had a significant and positive impact only on the first decile SOC content (Fig. 5). However, when considering the destination of the LM, the amount of herbivore manure spread on crops had a significantly positive impact on most values of SOC content (except for its first decile) (Fig. 4) and on median values of the change in SOC (see Table 3 in supplementary materials). These results, obtained at a national scale, consolidate the literature on (Fließbach et al. 2007) and regional analysis of (Goidts and van Wesemael 2007; Capriel 2013) livestock and LM impacts on SOC content. However, the impact of granivore manure spread on SOC content and dynamics in crop areas was negative or non-significant. This may have been due to the nature of the LM: in 2000 and $2010,30 \%$ of granivore manure was liquid compared to only $7 \%$ of herbivore manure. Indeed, due to their respective diets, granivore manure contains less fibrous material than herbivore manure. As a consequence, the $\mathrm{C} / \mathrm{N}$ ratios of the manures are different, with higher $\mathrm{C} / \mathrm{N}$ ratio for herbivore manure than for granivore manure. This affects the kinetics degradation of their organic matter in soils. With low $\mathrm{C} / \mathrm{N}$ ratio (lower than the ratio that characterizes the soil biomass biologic activity), as in granivore liquid manure, the soil biomass will not only consume the carbon and nitrogen from the manure but also soil carbon in order to maintain its biologic activity. In cases where crop residues are exported, SOC content will decrease. With high $\mathrm{C} / \mathrm{N}$ ratio, as in herbivore manure, it is the opposite dynamics. Hence, organic matter from granivore manure is less stable than of herbivore manure, and less suitable to maintain or increase SOC content (Velthof et al. 2000). This is consistent with certain technical reports, in which spreading liquid LM on crops decreased SOC content but doing so on grasslands increased it (Bodet 2001). This negative impact of 
spreading liquid LM instead of solid LM, together with insufficient straw incorporation and small proportion of green manure in the crop rotations, has been highlighted at a regional scale in Bavaria, Germany (Capriel 2013).

\subsection{Bias and interest of the databases used}

The results must be interpreted in light of the limits of the databases used in our analysis. The soil test results in BDAT are requested by farmers, usually to manage their fertilization and the general conditions of their fields (Saby et al. 2008). These samples come mainly from crop soils with high production potentials rather than grassland soils. Furthermore, the distribution of the samples varies in time and space (Saby et al. 2014). The commercial policies of soil analysis laboratories and agricultural advisors influence the soil analysis chosen and the plot sampled (Lemercier et al. 2006). The data used here, which are calculated summary statistics by canton and for 5-year periods, limited this potential bias.

The impact of spreading granivore manure on crops must be considered carefully. The change in the number of granivores was calculated from the agricultural censuses of 2000 and 2010. Although we assumed that the change in pigs and poultry was continuous, their numbers vary according to demand (especially for poultry), which may have biased analysis and interpretation. In contrast, numbers of cattle are more stable in time and have slower dynamics. More cantonal data relative to spreading manure practices and livestock could allow us to better explain the local trends in terms of SOC dynamics that can be masked on a larger scale.

There are also omitted variables that may impact SOC content that we did not consider here, such as sludge from plants treating waste waters or long-distance exchanges of organic matter. Such variables may have an impact on SOC measures, especially in areas with low SOC content.

Despite these limits, the databases used allowed us to perform statistical analysis at the national scale in 2365 cantons. At the national scale, spreading of LM influenced SOC content and dynamics significantly. Our results show the importance of the nature of the manure: solid manure increased SOC content, unlike liquid manure. Spreading herbivore manure on crops increased SOC content, but spreading granivore manure decreased it. These results could be consolidated using updated data from the 2020 French agricultural census and 2015-2019 BDAT data.

\section{Conclusion}

The objective of the study was to improve understanding of impacts of livestock farming on soils at the national scale in France. Our results suggest that livestock farming has an important role in maintaining and increasing soil organic carbon content, through how manure is managed. Our results, obtained for 2365 French cantons for a 10-year period, confirmed previous results of livestock manure spreading on soil organic carbon content and dynamics, in particular the positive influence of spreading herbivore manure. These results confirm those of previous studies at smaller geographical scales. Spreading herbivore manure on crop areas increases soil organic carbon content, but spreading granivore manure appears to decrease it. Livestock manure spread on grasslands has no significant impact on soil organic carbon content, likely due to under-representation of grassland soils in the French soil test database. The nature of the manure is important to consider. Whether livestock manure is applied in solid or liquid form can have opposite effects on soil organic carbon content: spreading solid livestock manure increases soil organic carbon content, while spreading liquid livestock manure may decrease it. These results demonstrate the importance of the complementarity between crop and livestock as a mechanism to maintain soil ecosystem services, including soil fertility and carbon sequestration. Our study demonstrates that soil data collected for a different purpose in the past can be used to study soil organic carbon dynamics that are relevant today.

Supplementary Information The online version contains supplementary material available at https://doi.org/10.1007/s13593-021-00682-3.

Acknowledgments The authors thank the other participants of the soil working group of the GIS "Avenir Elevages" (Scientific Consortium for the Future of Livestock), in particular Pierre Mischler. The soil-test database was funded by the French Ministry for Agriculture in the framework of a Scientific Group of Interest, the Groupement d'Interêt Scientifique Sol. We thank the soil-test laboratories participating in this program.

Code availability The code used in the current study is available from the corresponding author on reasonable request.

Authors' contribution Conceptualization: M.C., F.D., P.D., V.M., and N.S. Methodology: M.C., F.D., P.D., V.M., and N.S. Validation: M.C., A.I., F.D., P.D., V.M., and N.S. Formal analysis: M.C., A.I., F.D., P.D., V.M., and N.S. Investigation: M.C., A.I., F.D., P.D., V.M., and N.S. Writing - original draft: M.C. and A.I. Writing — review and editing: M.C., A.I., F.D., P.D., and N.S. Funding acquisition: P.D. and N.S. Resources: F.D., P.D., V.M., and N.S. Supervision: F.D., P.D., and N.S.

Funding This study was supported by the ANR project SoilServ (no. ANR-16-CE32-0005).

Data Availability The datasets generated during and/or analyzed in the current study are available on Data INRAE (doi:10.15454/37HUT7).

\section{Declarations}

Conflict of interest The authors declare that they have no conflict of interest.

Open Access This article is licensed under a Creative Commons Attribution 4.0 International License, which permits use, sharing, adaptation, distribution and reproduction in any medium or format, as 
long as you give appropriate credit to the original author(s) and the source, provide a link to the Creative Commons licence, and indicate if changes were made. The images or other third party material in this article are included in the article's Creative Commons licence, unless indicated otherwise in a credit line to the material. If material is not included in the article's Creative Commons licence and your intended use is not permitted by statutory regulation or exceeds the permitted use, you will need to obtain permission directly from the copyright holder. To view a copy of this licence, visit http://creativecommons.org/licenses/by/4.0/.

\section{References}

ADEME (French Environment and Energy Management Agency) (2007) Bilan des flux de contaminants entrant sur les sols agricoles de France métropolitaine - final report: Bilan qualitatif de la contamination par les éléments tracés métalliques et les composés tracés organiques et application quantitative pour les éléments tracés métalliques

Bellamy PH, Loveland PJ, Bradley RI, Lark RM, Kirk GJD (2005) Carbon losses from all soils across England and Wales 19782003. Nature 437(7056):245-248. https://doi.org/10.1038/ nature 04038

Blair N, Crocker GJ (2000) Crop rotation effects on soil carbon and physical fertility of two Australian soils. Soil Res 38(1):71. https:// doi.org/10.1071/sr99064

Bodet J (2001) Fertiliser avec les engrais de ferme. Institut de l'Élevage, Paris

Capriel P (2013) Trends in organic carbon and nitrogen contents in agricultural soils in Bavaria (south Germany) between 1986 and 2007. Eur J Soil Sci 64(4):445-454. https://doi.org/10.1111/ejss. 12054

Chen S, Arrouays D, Angers DA, Chenu C, Barré P, Martin MP, Saby NPA, Walter C (2019) National estimation of soil organic carbon storage potential for arable soils: a data-driven approach coupled with carbon-landscape zones. Sci Total Environ 666:355-367 doi. org/10.1016/j.scitotenv.2019.02.249

Curien M (2018) Liens entre pratiques agricoles et teneur en carbone organique des sols dans les systèmes en polyculture-élevage. Dissertation, Mémoire de Master 2, Agrosciences, Environnement, Territoires, Paysage, Forêt. Paris : AgroParisTech, 51p.

De Gruijter J, Brus DJ, Bierkens MF, Knotters M (2006) Sampling for natural resource monitoring. Springer Science \& Business Media, New York City

Depeyrot JN, Perrot C, Dedieu MS (2015) Les fermes laitières de polyculture-élevage : atouts et défis pour l'avenir. Centre d'études et de prospectives, Analyse 86:1-8

Dumont B, Dupraz P, Donnars C (2019) Impacts et services issus des élevages européens. doi:https://doi.org/10.35690/978-2-7592-2705-1

Fließbach A, Oberholzer HR, Gunst L, Mäder P (2007) Soil organic matter and biological soil quality indicators after 21 years of organic and conventional farming. Agric Ecosyst Environ 118(1-4):273284. https://doi.org/10.1016/j.agee.2006.05.022

Goidts E, van Wesemael B (2007) Regional assessment of soil organic carbon changes under agriculture in Southern Belgium (19552005). Geoderma 141(3-4):341-354. https://doi.org/10.1016/j. geoderma.2007.06.013

Institut de l'élevage (2007) Evaluation des durées de présence en bâtiments par régions administratives et par OTEX. Extrait base de données PMPOA II, Dossier NOPOLU gaz à effet de serre.

Issanchou A (2017) Gestion de la variation de la qualité des sols par les agriculteurs: enjeux pour la rentabilité et la durabilité des exploitations agricoles françaises. Doctoral dissertation, Rennes, Agrocampus Ouest.
Joly D, Brossard T, Cardot H, Cavailhes J, Hilal M, Wavresky P (2010) Les types de climats en France, une construction spatiale. Cybergeo. https://doi.org/10.4000/cybergeo.23155

Lemercier B, Walter C, Schvartz C, Saby NPA, Arrouays D, Follain S (2006) Suivi des teneurs en carbone organique et en phosphore extractible dans les sols agricoles de trois régions françaises. Etude et Gestion des Sols, Association française pour l'étude des sols, 13 (3):165-180. hal-01924381

Loveland P, Webb J (2003) Is there a critical level of organic matter in the agricultural soils of temperate regions: a review. Soil Tillage Res 70(1):1-18. https://doi.org/10.1016/s0167-1987(02)00139-3

Martin MP, Orton TG, Lacarce E, Meersmans J, Saby NPA, Paroissien JB et al (2014) Evaluation of modelling approaches for predicting the spatial distribution of soil organic carbon stocks at the national scale. Geoderma 223-225:97-107. https://doi.org/10.1016/j. geoderma.2014.01.005

McSherry ME, Ritchie ME (2013) Effects of grazing on grassland soil carbon: a global review. Glob Chang Biol 19(5):1347-1357. https:// doi.org/10.1111/gcb.12144

Meersmans J, Martin MP, Lacarce E, De Baets S, Jolivet C, Boulonne L et al (2012) A high resolution map of French soil organic carbon. Agron Sustain Dev 32(4):841-851. https://doi.org/10.1007/s13593012-0086-9

Paroissien JB, Degan F, Perrot C, Philibert A, Saby NPA, Martin M, Gouny L, Dupraz P, (in review) Évolution des teneurs en carbone organique dans les régions d'élevage en France entre 1990-2014

Pinheiro J, Bates D, DebRoy S, Sarkar D, R Core Team (2020) nlme: Linear and nonlinear mixed effects models. R package version 3.1515

R Core Team (2018) R: a language and environment for statistical computing. R Foundation for Statistical Computing, Vienna

Saby NPA, Arrouays D, Antoni V, Lemercier B, Follain S, Walter C, Schvartz C (2008) Changes in soil organic carbon in a mountainous French region, 1990-2004. Soil Use Manag 24(3):254-262. https:// doi.org/10.1111/j.1475-2743.2008.00159.x

Saby NPA, Lemercier B, Arrouays D, Leménager S, Louis BP, Millet F, Paroissien JB, Schellenberger E, Squividant H, Swiderski C, Toutain B, Walter C, Bardy M (2014) Le programme Base de Données des Analyses de Terre (BDAT) : Bilan de 20 ans de collecte de résultats d'analyses. Etude et Gestion des Sols 21: 2536. hal-01209243

Schvartz C, Walter C, Claudot B, Bouedo T, Aurousseau P (1997) Synthèse nationale des analyses de terre réalisées entre 1990 et 1994: I. Constitution d'une banque de données cantonale. Etude et gestion des sols 4(3):191-204

Sierra J, Causeret F, Chopin P (2017) A framework coupling farm typology and biophysical modelling to assess the impact of vegetable crop-based systems on soil carbon stocks. Application in the Caribbean. Agric Syst 153:172-180. https://doi.org/10.1016/j. agsy.2017.02.004

Sleutel S, De Neve S, Hofman G, Boeckx P, Beheydt D, Van Cleemput $\mathrm{O}, \ldots$ Verbeeck H (2003) Carbon stock changes and carbon sequestration potential of Flemish cropland soils. Glob Chang Biol 9(8): 1193-1203. doi:https://doi.org/10.1046/j.1365-2486.2003.00651.x

Soussana JF, Loiseau P, Vuichard N, Ceschia E, Balesdent J, Chevallier T, Arrouays D (2004) Carbon cycling and sequestration opportunities in temperate grasslands. Soil Use Manag 20(2):219-230. https:// doi.org/10.1111/j.1475-2743.2004.tb00362.x

Swiderski C, Saby N, Party JP, Sauter J, Köller R, Vandijk P et al (2012) Evolution des teneurs en carbone organique dans l'horizon de surface des sols cultivés en Alsace: Analyse à partir de la Base de Données des Analyses de Terre. Étude et Gestion des sols 19(3-4): 179-192

Velthof G L, Bannink A, Oenema O, van der Meer H G, Spoelstra S F (2000) Relationships between animal nutrition and manure quality; a literature review on $\mathrm{C}, \mathrm{N}, \mathrm{P}$ and $\mathrm{S}$ compounds. Alterra 63. 
Wageningen: Alterra. https://library.wur.nl/WebQuery/wurpubs/ 311738.

Wadoux AMJ, Minasny B, McBratney AB (2020) Machine learning for digital soil mapping: applications, challenges and suggested solutions. Earth Sci Rev 210:103359. https://doi.org/10.1016/j.earscirev. 2020.103359

West TO, Post WM (2002) Soil organic carbon sequestration rates by tillage and crop rotation. Soil Sci Soc Am J 66(6):1930-1946. https://doi.org/10.2136/sssaj2002.1930

Xiao Y, Mignolet C, Mari JF, Benoît M (2015) Characterizing historical (1992-2010) transitions between grassland and cropland in mainland France through mining land-cover survey data. J Integr Agric 14(8):1511-1523. https://doi.org/10.1016/s2095-3119(15)61103-0
Yang X, Kay B (2001) Rotation and tillage effects on soil organic carbon sequestration in a typic Hapludalf in Southern Ontario. Soil Tillage Res 59(3-4):107-114. https://doi.org/10.1016/s0167-1987(01) 00162-3

Zeileis A, Hothorn T (2002) Diagnostic checking in regression relationships. R News 2(3):7-10

Publisher's note Springer Nature remains neutral with regard to jurisdictional claims in published maps and institutional affiliations. 